\title{
Geological Research In and Around Nubia
}

\author{
by E.H. Klitzsch
}

\begin{abstract}
The future of countries in arid and semiarid regions depends to a large extent on the understanding and development of their desert areas. In this article the author discusses the objectives and some of the achievements of a major research program now being carried out by German, Egyptian and Sudanese scientists in NE Africa. He also points out some of the problems of working in the vast desert areas of Nubia that span northern Sudan and southern Egypt.
\end{abstract}

\section{The Need for Geological Research in Arid Regions}

In many of the desert and semidesert regions of the world, there are major geological basins filled with more or less permeable sediments that contain large quantities of groundwater. Much of this water is fossil and is renewed during wet periods, but in general the recharge situation is in doubt or unknown. For practical purposes of groundwater usage, it is necessary to understand and quantify the mechanism of natural recharge, the movement and discharge of groundwater in these basins in relationship to the changing climatic situation and, of course, to assess the groundwater reserves.

The groundwater situation can, however, only be properly evaluated against the background of a well-established structural and stratigraphical basin analysis which characterizes the physical and geometrical properties of the strata and their basement. In addition to the different classical methods of geological investigations, techniques of remote sensing, geodesy, photogrammetry and geophysics have to be applied. It is also essential to consider fully the conflicting potentials for the use of groundwater, for example, agriculture, ecology and the need to "dress" or upgrade local mineral deposits with large quantities of water.

It is within this general context that the German research project "Geoscientific Problems of Arid Areas" (SFB/69) has been established. The ultimate aim of the project is to define criteria for the use (and the limits of that use) of groundwater in arid and semiarid regions. Because the investigators involved were already engaged in research in northeastern Africa, parts of the desert of Egypt and northern Sudan were chosen as the site for the first case study. Here the large agricultural development schemes of the New Valley area in the Western Desert of Egypt depend on groundwater. However neither the stratigraphical nor the structural situation of the aquifers was sufficiently known within the recharge areas of Egypt and northern Sudan. $\mathrm{SFB} / 69$ is therefore aimed at establishing the scientific basis necessary for groundwater development here, and it is expected that many of the results will be applicable to other regions.

\section{Development of the Research Project}

My own first geological involvement in North Africa, from 1958 until 1967, was controlled by the need to subdivide and define the Palaeozoic and Mesozoic strata of basins in and around Libya in order to understand the structural and palaeogeographical development of that region (summary in Klitzsch, 1970). One of the major conclusions of this early work was that throughout Palaeozoic and Mesozoic times the marine part of the stratigraphic column decreases in importance to the south and east. The eastern Sahara was reached by very few and shallow transgressions; erosion and continental sedimentation prevailed. Had we not understood the stratigraphic column of southwestern and western Libya or of southeastern Algeria, the stratigraphy of northern Chad and southeastern Libya would still be largely undefined.

One of the major reasons why so little was known until recently about the geology of a large part of the desert areas of Egypt and Sudan was that there are no obvious key horizons like the graptolitic Silurian shale of the central and western Sahara. Stratigraphical research in the eastern Sahara below the marine Cretaceous and Tertiary is rather hopeless if one does not understand the more readily established stratigraphy fur ther west.

Because of the general lack of stratigraphical knowledge of large areas in North Africa and the Near East, the term "Nubian Sandstone" has been widely used to characterize Palaeozoic and Mesozoic strata, the age and origin of which was known only tentatively (see Pomeyrol, 1968 for a summary). I am convinced that it does not really matter now in which sense the term Nubian Sandstone is used, because within a short time there will be a relatively detailed subdivision of strata in and around Nubia and an environmental interpretation of its different stratigraphical units (Fig. 1).

Prior to the first phase of our research in Egypt and Sudan (1976-1981), there was very little literature of stratigraphical value on the pre-upper Cretaceous strata of northwestern Sudan and southwestern Egypt (Menchikov, 1926; Sandford, 1935; Said, 1962, 1971; Issawi, 1968). Indeed the large 


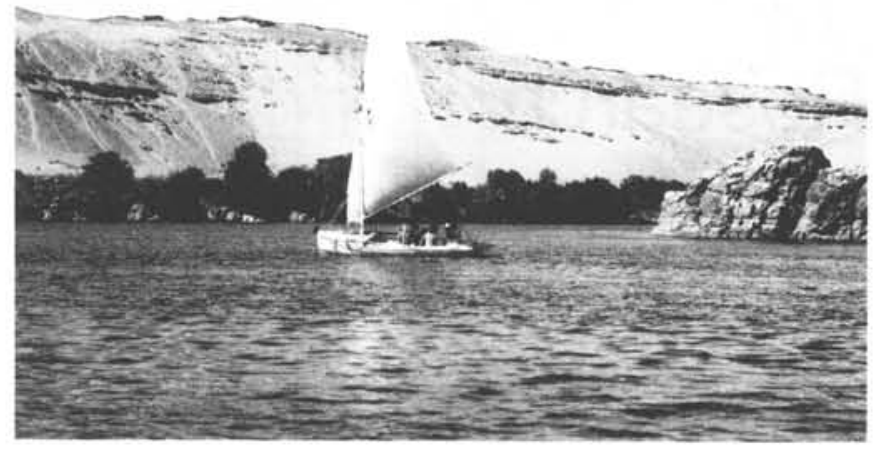

Figure 1: The River Nile at Aswan. Shallow marine and fluvial strata of middle Cretaceous age resting on Precambrian granite. Nubia begins here and reaches far to the south and southwest.

plateau landscape of Gilf Kebir first became known only in 1928 (Kemal el Din). Scientists of the present project have visited many escarpments, plateaus and wadis not previously recorded, and the largest unexplored geological feature found was a 100 by $100 \mathrm{~km}$ plateau covered by Tertiary marine limestone and called by the local nomads Gebel Abiat ("White Mountains").

Much of the early geological work in this region was on aspects of only marginal importance for the geological history of the Eastern Sahara, e.g., the origin of the so-called Libyan silica glass, the formation of meteoric craters and the structure of dunes (see cover). Egyptian scientists, mainly of the Geological Survey and the universities, did much excellent work on the marine strata and Precambrian rocks of northern Egypt, along the Nile Valley, at the Red Sea and in Sinai. The vast desert areas in the southwest, however, remained almost unexplored until recently. Even less had been done in northwestern Sudan, a region so difficult to reach from Khartoum that most of the current research here has been done, with Sudanese permission, by working across the Egyptian border (Fig. 2).

During the first phase of our research (1976-1981) a preliminary geological and topographical map was compiled at 1:500000 for most of the Western Desert of Egypt and nor thern Sudan as far south as Wadi Howar (Klitzsch and List, 1980, and unpublished sheets of Sudan prepared by Schmitz). The map resulted from a combination of fieldwork and remote sensing techniques.

A first stratigraphical subdivision of strata in southwestern Egypt has now been established (Klitzsch, 1978; Barthel and Böttcher, 1978; Klitzsch and others, 1979; Barthel and Herrmann-Degen, 1981; Léjal-Nicol and Boureau, 1981; Böttcher, 1982; Bisewski, 1982). The hydrogeological situation of the Dakhla Basin has been tentatively analyzed (Thorweihe, 1982), and Pachur and Braun (1980) have investigated the Late Pleistocene to Holocene climatic development.

This work has been carried out in close cooperation with Prof. E.M. El Shazly of the Egyptian Academy of Sciences. The main funding came from the German Research Foundation (Deutsche Forschungsgemeinschaft - DFG). Part of the remote sensing and of the fieldwork was carried out with the help of Continental Oil Company, which was exploring the Western Desert of Egypt at the same time and which gave us unusually free access to much of their data.
The successes of this initial research lead the DFG to encourage expansion of the project to the status of "Special Research Project" (Sonderforschungsbereich - SFB), the high est category of funding of scientific research in the Federal Republic of Germany. This was done in mid-1981, and the expanded project is expected to complete its work in and around Nubia by 1986, after which another arid to semiarid region of Africa will be studied.

A total of 95 scientists are now participating in nineteen subprojects related to 1) basin analysis, 2) hydrogeology and isotope hydrology, climate, Quaternary geology and pedology, 3) sedimentary deposits (mineral potential and ore dressing), 4) remote sensing, cartography and geophysics and 5) centra! analytical services and coordination. The German research organizations involved are the Technical University of Berlin, the Free University of Berlin, the Polytechnicum of Berlin, the Hahn-Meitner Research Institution of Berlin and the University of Heidelberg.

SFB/69 is being carried out in close cooperation with Egyptian and Sudanese colleagues, and there is provision for the exchange of scientists. Apart from this, a number of North African Ph.D. candidates are involved, with their postgraduate research sponsored by German Academic Exchange Service or by their own governments. For the period 1981-84, cooperative agreements have been signed with the General Petroleum Company of Egypt, which carries out groundwater research for the Egyptian government, and with the Geological Survey of Egypt, as well as with the Ministry of Energy and Mining of Sudan. SFB/69 will also participate in IGCP projects such as 184 on Palaeohydrology of Low Latitude Deserts and 210 on Continental Sediments in Africa.

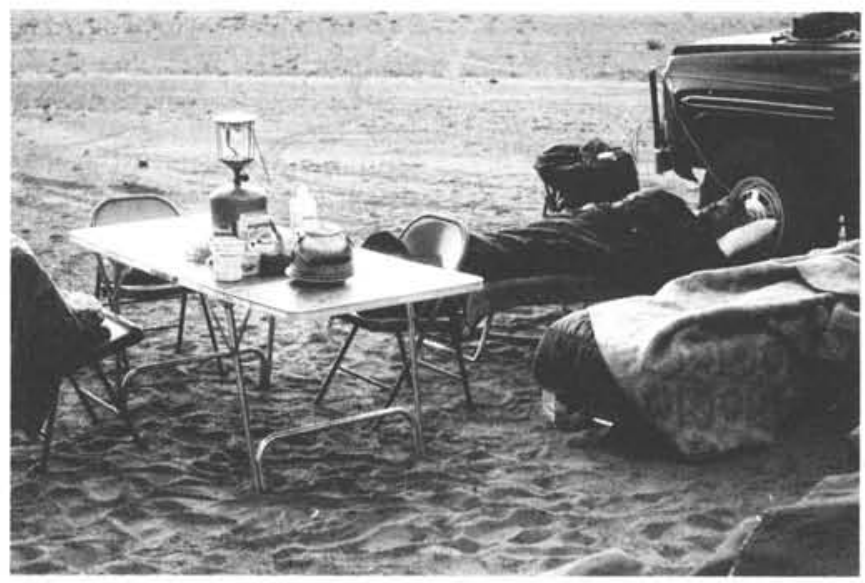

Figure 2: Geological field party in Nubia. We travel without tents, sleeping in the lee of the cars when we stop at sunset. Since we do not depend on camps, large areas can be covered in relatively short time.

\section{General Stratigraphy of Nubia and Adjacent Regions}

Between the New Valley at the southeastern edge of the Dakhla Basin (Fig. 3) and the Gilf Kebir area near the Libyan border, where our work began, the strata below the fully marine sediments of late Cretaceous age consist of six stratigraphic formations with unique characteristics over a distance of 600 kilometers. These strata rest directly on Precambrian basement, and their ages range from Jurassic to late Cretaceous. At Gilf Kebir the Mesozoic formations to the north, southwest and west overlie unfolded Silurian to Carboniferous sediments.

Recognition of these strata in the transitional area between Kufra and Dakhla basins was the next step. Later the area east and southeast of Gebel Uweinat in northern Sudan was included, and here Silurian as well as late Devonian to Carboniferous sediments were identified (Klitzsch 1980). 

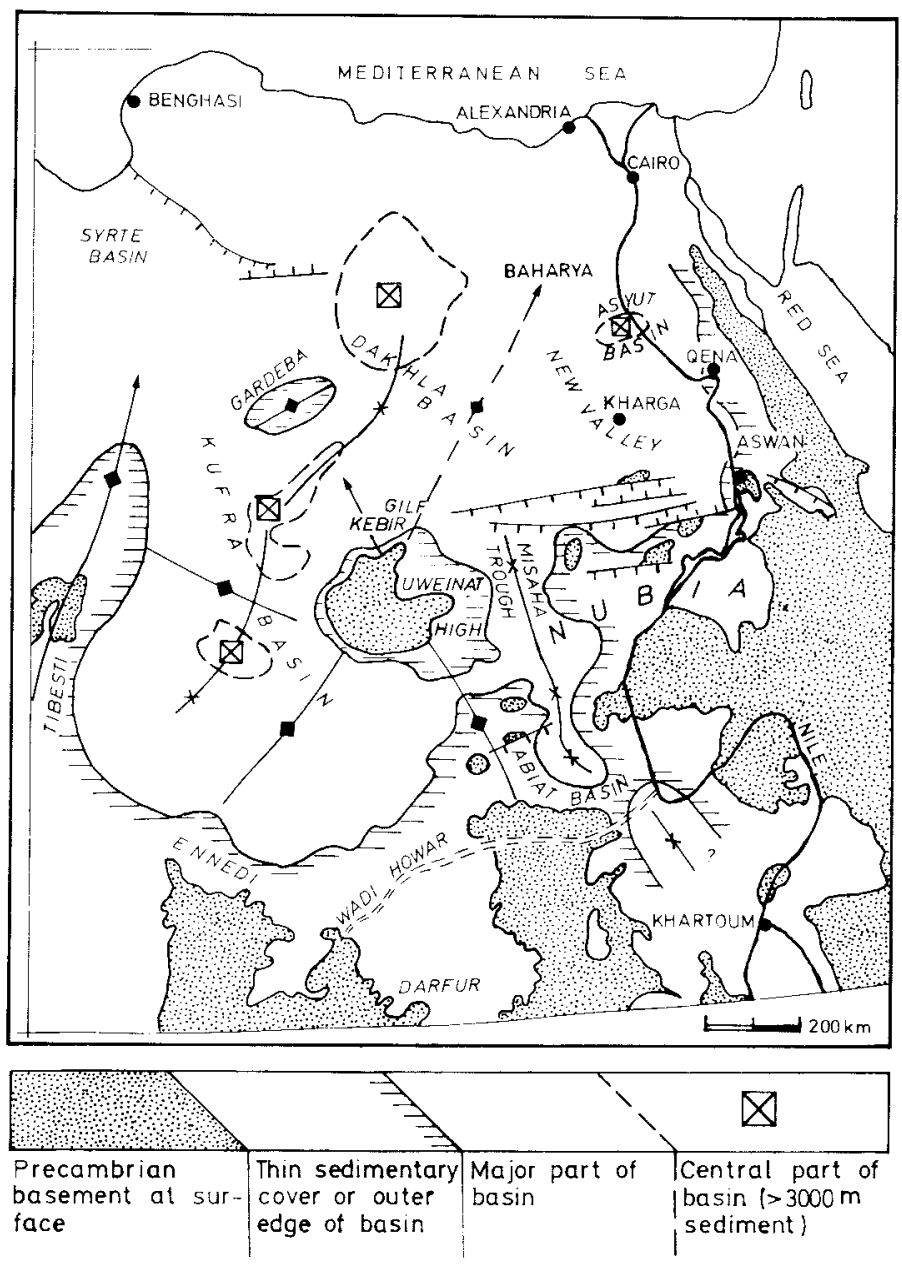

$r r_{\text {major }}^{\text {major }}$
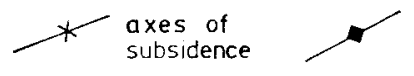

axes of reduced subsidence or of uplift

Figure 3: Structural interpretation of parts of the Eastern Sahara.

Sandstone of Carboniferous age had been known from the Sudanese part of Gebel Uweinat, where it rests directly on Precambrian basement (Menchikov, 1926). A little to the north, in the Egyptian part of Gebel Uweinat, and also directly east of this high mountain area, Silurian and Devonian sandstone underlie the Carboniferous beds.

This whole flat-lying Palaeozoic sequence is truncated eastward by continental sandstone of Jurassic and Early Cretaceous age, which themselves rest directly on Precambrian metamorphics and granite further to the east. The same eastward truncation of Palaeozoic strata was observed in the Abu Ras-Gilf Kebir area. Here Silurian, Devonian and Carboniferous strata, which are well exposed at Wadi Abd el Malik and south of the Abu Ras Plateau in the Gilf Kebir area (Klitzsch 1979; Seilacher, 1983), disappear eastward. We are convinced that there is no major occurrence of Palaeozoic strata exposed between the Gilf Kebir-Gebel Kamil area and the Aswan area. Within this whole region, strata of Palacozoic age, where present, were eroded during Permo-Triassic time.

Along the southern edge of the Uweinat High and for some distance eastward, very immature continental sediments of Permo-Triassic age are present. These sediments were deposited within a south to southwestward drainage regime, a very unusual direction of transport in North Africa, where continental strata normally are the result of a northward drainage. We suggest that this reflects the presence of a regional high which ran along much of southern Egypt dumg Permo-Triassic time, causing drainage to the south. The Permo-Triassic strata south and southeast of Uweinat ure overlain by continental strata of Jurassic, Early Crctaccous and middle to upper Cretaceous age. These were all deposited under more or less normil northward directions of transport (Fig. 4).

Identification and correlation of strata along the northwestern and western edge of Nubia is thus relatively clar. More problematic are the stratigraphical relationships from the southern Dakhla Basin eastward towards Lake Nasser (south of Aswan) and the Eastern Desert region, and southward towards the Abiat Basin. Four to five formations of Jurassic to middle Cretaceous age can be recognized between the Misaha Trough and the Abiat Basin. The distribution of the overlying late Cretareous strata is controlled by structural events or by palaeorclicf, or both, but further wors is required before a satisfactory interpretation of these mijor parts of Nubia can be developed.

An unexpected result of the present research was the ifscovery of marine clastics of late Cretaceous age and of carbonates of probable early Tertiary age at Gebel Abiat. These orcur $400 \mathrm{~km}$ south of similar strata in Egypt which mark what was thought to be the southern edge of iate Cretaceous to early Tertiary transgressions. It is difficul: to imagine that the sea which deposited limestone of early Tertiary age came from any other direction than from the north or nor theast. Thus it appears that the sea transgressed southward through relatively short periods, filling in preexisting relief. Further south, in the Khartoum area, strata of probable Eocene age form part of the continental Nubian Sandstone (A. Léjal-Nicol and G. Prasad, personal comminication, 1983).

Recent investigations of other groups working in the Eastern Desert of Egypt will help to correlate the different formations of Nubia with the Eastern Desert of Egypt (Ward und MacDonald, 1979; van Houten and Bhattacharyya, 19\%9; Issawi and Jux, 1982). There are, however, some major differences in observation and interpretation which will be published later.

In summary then, Palaeozoic sediments are present along the eastern edge of the Kufra Basin in the areas southeast and south of Gebel Uweinat, and west as well as northwest of cillf Kebir. They consist of shallow marine to fluvial Silurian sediments deposited on both sides of the extreme solitheastern edge of the early Silurian sea. Above these beds lic fluvio-continental Devonian strata and marine to fluviom continental and glacial sediments of Carboniferous age (Klitzsch, 1983; Seilacher, 1983). Along the southern edge of Dakhla Basin, Palaeozoic strata and older rocks were eroled during Permo-Triassic time and partly redeposited in Nubia. From Jurassic to middle Cretaceous time, a very stable and flat relief prevailed with deposition of fluvial sediments in northward-flowing regimes of dranage. During the Aptian and Cenomanian some very shallow transgressions came from the north, temporarily extending into northern and eastern Nubia. Finally in the late Cretaceous to early Tertiary the invading sea reached southern Nubja, depositing marine shile. sandstone and limestone. Afterwards, the formation of the present landscape began and remaining deposition was purely continental.

During the entire period from the deposition of PerraTriassic strata in western Nubia until the late Cretaceous transgressions, the climate must have been predominarily humid, for the fluvial and lacustrine sediments are full of palaeosoils, wood, roots and other plant remains (Fig. 5). Marine sediments were deposited locally in lagoonal environ ments with mangrove-type vegetation. There are, however. very few indications of an arid environment during this long period of time within the strata of Nubia. 


\section{Regional Structure}

The overall stuctural setting of the research area is simple (Fig. 3). Since early Palaeozoic time vertical movements in this part of the African craton have been very slow and epeirogenetic in nature, with only local interruption by faults. Some of these can be traced over large distances, but most, however, resulted in only minor displacements. Neither do horizontal movements seem to have been impressive. The epeirogenetic vertical movements lead to the formation of large basins, which are now filled with up to $4500 \mathrm{~m}$ of sediment and bordered by zones of minor subsidence or of uplift. Over large distances the Precambrian basement is at the surface or under thin sedimentary cover.

Within the central Sahara, the stuctural development follows fairly regular patterns, with an older NNW-striking pattern and a younger one with an approximately NE orientation (Klitzsch, 1970). Young volcanism is found where these patterns cross, or on the edges of uplifts or grabens. Many of the observations made in Libya and northern Chad may apply equally to Egypt and Sudan, but this can not yet be fully substantiated.

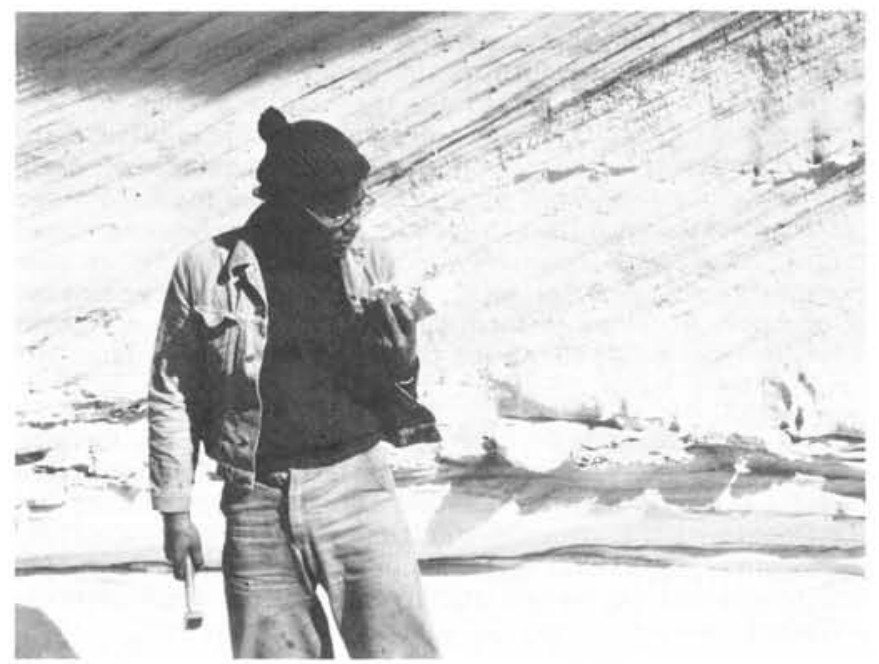

Figure 4: Zaid Jamal sampling crossbedded Early Cretaceous sandstone in southwestern Egypt.

The present research area is dominated by the Kufra and Dakhla Basins, both up to 800 by $800 \mathrm{~km}$ wide and more than 3500 or $4000 \mathrm{~m}$ deep (Beall and Squyres, 1980). They are mainly filled with strata of Palaeozoic and Mesozoic age. The Palaeozoic rocks are partly marine, but marine Mesozoics are only present in the Dakhla Basin.

The dividing element between the two basins is an old, (probably early Palaeozoic) NNW-striking uplift extending from the eastern part of Wadi Howar in Sudan across the Uweinat High towards Gebel Gardeba. Between Uweinat and Gardeba during Mesozoic times this uplift was included in the subsidence of the NE-trending trough (Fig. 3) which now connects the two basins and which is of great hydrogeological importance. A similar connection between the southern part of the Kufra Basin and the southern edge of the Dakhla Basin exists southeast and east of the Uweinat High, but the subsidence here was not as marked as that north of the Uweinat High.

The sediments east of the Howar-Uweinat uplift seem to be shallow. Around Bir Misaha and possibly at Gebel Abiat relatively small basins of minor importance developed parallel to the Howar-Uweinat uplift. It is possible that between the eastern end of Wadi Howar and Khartoum stronger subsidence took place; the same may be the case south of the western part of Wadi Howar. Both areas will be investigated during the coming seasons.
To the west and southwest of Aswan there are several very long east-west faults with vertical displacement of Mesozoic and Ter tiary strata of up to several hundred meters. In some places, impermeable basement forms the northern uplifted side of faults, causing a permeability barrier and giving rise to fresh water wells.

East of Aswan, NW-striking faults with up to $2000 \mathrm{~m}$ displacement formed during middle Cretaceous time, prior to the formation of the Red Sea Graben; the downfaulted blocks were filled with sediments mainly transported from the east and southeast. The faulting east and west of Aswan was locally accompanied by basaltic volcanism.

During Tertiary time a large area between Uweinat and Bahariya was affected by volcanic activity resulting mainly in ring structures, but also locally in pipes, small volcanoes or basalt blankets. The Uweinat area itself is characterized not only by basaltic activity but also by large acid to intermediate intrusions of Tertiary age.

\section{Groundwater Situation}

Until 3000-3500 years ago, the climatic situation of the research area was different from the present. Pachur and Braun (1982) have proven the existence of ancient river systems between the Tibesti mountains in Chad as well as between the Gilf Kebir and the Sirte areas. Issawi (1983) and several others meanwhile have used shuttle radar imagery to demonstrate the existence of palaeorivers in the Eastern Sahara.

Sonntag and others (1978 and 1982) have investigated the age of Saharan groundwater and related it to pluvial periods in North Africa, which partially correlate with glacial periods in Europe. One of the major findings is that recharge of groundwater along the northern, central and eastern parts of the Sahara was mainly through frontiers of rainfall originating from the Atlantic. Only the southern regions have been recharged by tropical monsoon rainfalls. The deuterium content of ground water reflects very well the distance towards the coastal area, where those clouds originated which recharged the groundwater. Thus the recharge situation of moister periods is relatively well reconstructed. It was during these periods that the large sedimentary basins were filled with fresh water. Meanwhile we also have a relatively clear control over the geological and structural connections of the different basins and their present groundwater content. We have the impression that most ground water has not migrated over large distances as postulated by several authors in the past. According to the deuterium content of the samples we have analyzed until now, most

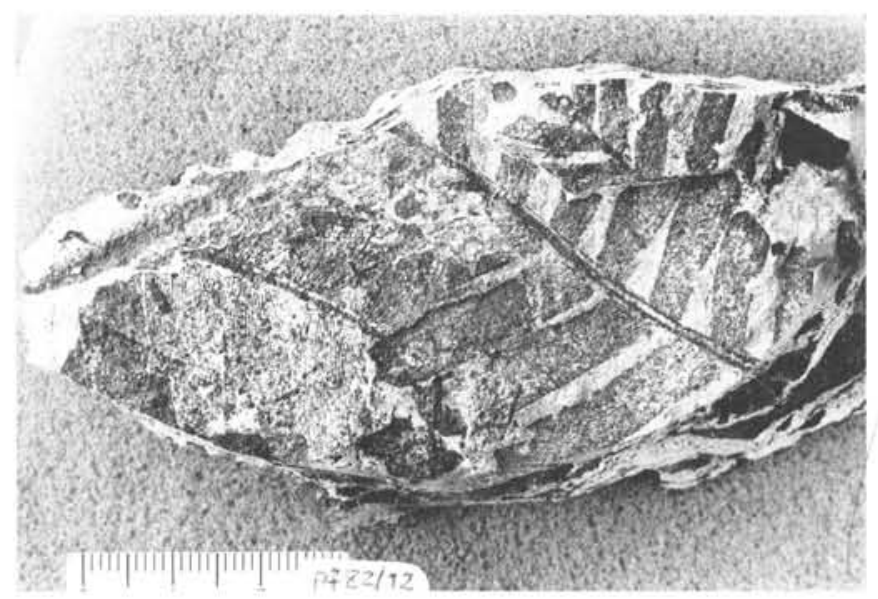

Figure 5: Flora from Mesozoic (probably Jurassic) sandstone near Selima. A new species of Pterophyllum (Pterophyllum nubiense, A. Lejal-Nicol, 1983), scale in centimeters and millimeters. 
groundwater is more or less in the areas where it originated in palaeorainfalls.

Our knowledge about present recharge and about natural discharge under present conditions is, however, still rudimentary and has to be improved during the next few years. As regards the transport of moisture between the groundwater table and the surface, studies based on the concentration of stable isotopes near undisturbed groundwater tables indicate a much deeper influence of evaporation under the present climate than previously expected (personal communication, Sonntag, Schneider and Thorweihe, 1983). The regional and quantitative aspects of groundwater flow in totally arid regions are also not sufficiently understood. Together with the depth of evaporation they will be major targets for future hydrogeological investigations.

There is no doubt that the groundwater reserves of the Western Desert of Egypt are in the order of $50000 \mathrm{~km}^{3}$ (Thorweihe, 1982). But as long as we do not completely understand the physics of natural discharge and recharge and its dependence upon changing climatic conditions, it is not possible to make sound conclusions about the use of these groundwater reserves. We intend, however, to reach conclusive results on groundwater, together with soil and mineral potentials, in Egypt and Sudan by the end of 1986.

\section{Acknowledgements}

I would like to thank the following organizations for substantial support and help: DFG, the Egyptian Academy of Science, the General Petroleum Company and the Geological Survey of Egypt, the Continental Oil Company Cairo, and the Geology and Minerals Department in Khartoum. My very best personal thanks go to Rushdi Said and Coy H. Squyres for constant encouragement.

\section{ABOUT THE AUTHOR:}

Prof. Dr. Eberhard H. Klitzsch began his professional career in 1958 as a petroleum geologist in Germany and North Africa and has since worked mainly at the interface between palaeogeography, structural geology and mineral and groundwater resources. $\mathrm{He}$ is the leader of the SFB/69 on "Geoscientific Problems of Arid Areas", and is based at the Technical University of Berlin (Hardenbergstr. 42, D-1000 Berlin 12, F.R.G.).

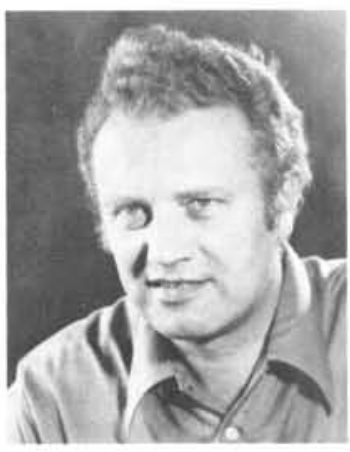

\section{References}

Barthel, K.W. and Böttcher, R., 1978. Abu Ballas Formation: a significant lithostratigraphic unit of the former "Nubian Series". Mitteilungen Bayerische Staatssammlung für Paläontologie und Historische Geologie, no. 18, p. 153-166.

Barthel, K.W. and Herrmann-Degen, W., 1981. Late Cretaceous and Early Tertiary Stratigraphy in the Great Sand Sea and its SE Margins (Farafra and Dakhla Oases), SW Desert, Egypt. Mitteilungen Bayerische Staatssammlung für Paläontologie und Historische Geologie, no. 21, p. 141-182.

Beall, A.O. and Squyres, C.H., 1980. Modern frontier exploration strategy, a case history from Upper Egypt. Oil and Gas Journal, v. 78 , no. 14 , p. $106-110$.

Bisewski, H., 1982. Zur Geologie des DakhlaBeckens (Südwest-Ägypten). Berliner Geowissenschaftliche Abhandlungen, Reihe A, 40, p. 1-86.

Böttcher, R., 1982. Die Abu Ballas Formation (Lingula Shale) der Nubischen Gruppe Südwest-Ägyptens. Berliner Geowissenschaftliche Abhandlungen, Reihe A, 39, 145p.

Issawi, B., 1968. The geology of Kurkur-DunguI area. U.A.R. Geological Survey, Paper no. 46, 102p.

Issawi, B., 1983. Ancient Rivers of the Eastern Egyptian Desert. Episodes, 1983, no. 2, p. 3-6.

Issawi, B. and Jux, U., 1982. Contributions to the Stratigraphy of the Paleozoic Rocks in Egypt. Geological Survey of Egypt Paper No. 64,28 p., Cairo.

Kemal el Din, H., 1928. L'exploration du désert de Libye. La Géographie, 1, p. 326.

Klitzsch, E., 1970. Die Strukturgeschichte der Zentralsahara; neue Erkenntnisse zum Bau und zur Paläogeographie eines Tafellandes. Geologische Rundschau, v. 59, no. 2, p. 459527.

Klitzsch, E., 1978. Geologische Bearbeitung Südwest-Ägyptens. Geologische Rundschau, v.67, no. 2, p. 509-520.

Klitzsch, E., 1979. Zur Geologie des Gilf Kebir Gebietes in der Ostsahara. Clausthaler Geologische Abhandlungen, v. 30,132p.
Klitzsch, E., 1980. Neue stratigraphische und paläogeographische Ergebnisse aus dem Nordwest-Sudan. Berliner Geowissenschaftliche Abhandlungen, Reihe A, 20,235p.

Klitzsch, E., 1983. Paleozoic formations and a Carboniferous glaciation from the Gilf Kebir-Abu Ras Area in Southwestern Egypt. Journal of African Earth Sciences, v. 1, no. 1, p. 17-19.

Klitzsch, E., Harms, J.G., Léjal-Nicol, A. and List, F.K., 1979. Major Subidvisions and Depositional Environments of Nubia strata, Southwestern Egypt. American Associa-tion of Petroleum Geologists Bulletin, v. 63, no. 6, p. 967-974.

Klitzsch, E. and List, F.K., 1980. Geological Interpretation Map Egypt, 1:500000, preliminary edition. TFH Berlin.

Léjal-Nicol, A. and Boureau, E., 1981. A propos de nouvelles flores paléozoiques et mésozoiques de l'Egypte du Sud-Ouest. Comptes Rendus Hebdomadaires des Seances de l'Académie des Sciences, v. 292, no. II, p. 1337-1340.

Menchikov, N., 1926. Observations géologiques faites au cours de l'expédition de S.A.S. le Prince Kemal-el-Dine Hussein dans le désert de Libye (1925-1926). Comptes Rendus Académie des Sciences, Paris, v. 183, p. 1047-1049.

Pachur, H.-J. and Braun, G., 1980. The Paleoclimate of the Central Sahara, Libya and the Libyan Desert. Palaeoecology of Africa, v. 12, p. 351-363.

Pachur, H.-J. and Braun, G., 1982. Aspekte paläoklimatischer Befunde in der östlichen Zentralsahara. Geomethodica, v. 7, p. 2354.

Pomeyrol, R., 1968. "Nubian Sandstone". American Association of Petroleum Geologists Bulletin, v. 52, no. 4 , p. 589-600.

Said, R., 1962. The Geology of Egypt. Elsevier, Amsterdam, 377p.

Said, R., 1971. Explanatory Notes to accompany the Geological Map of Egypt. Egypt Geological Survey, v. 56, 123p.

Sandford, K.S., 1935. Geological observations on the North-West frontiers of the Anglo-
Egyptian Sudan and the adjoining part of the southern Libyan Desert. Quarterly Journal Geological Society of London, v. XCI, part 3, p. 323-381.

Seilacher, A., 1983. Upper Paleozoic trace fossils from the Gilf Kebir-Abu Ras area in Southwestern Egypt. Journal of African Earth Sciences, v. 1, no. 1, p. 21-34.

Sonntag, C., Klitzsch, E., Löhnert, E.P., EI Shazly, E.M., Münnich, K.O., Junghans, C., Thorweihe, U., Weistroffer, K. and Swailem, F.M., 1978. Paleoclimatic Information from Deuterium and Oxygen-18 in C-14 dated North Saharian Groundwaters: Groundwater Formation in the Past: Isotope Hydrology, Proceeding of a Symposium. Neuherberg, $v$. II, p. 569-581, IAEA, Wien.

Sonntag, C., Thorweihe, U. and Rudolph, J., 1982. Isotopenuntersuchungen zur Bildungsgeschichte saharischer Paläowässer. Geomethodica, v. 7, p. 55-78.

Thorweihe, U., 1982. Hydrogeologie des Dakhla-Beckens, Ägypten. Berliner Geowissenschaftliche Abhandlungen, v. 38, p. 1-53.

van Houten, F.B. and Bhattacharyya, D.P., 1979. Late Cretaceous Nubia Formation at Aswan, Southeastern Desert, Egypt. Annals Geological Survey of Egypt, v. 9, p. 408419.

Ward, W.C. and MacDonald, K.C., 1979. Nubia Formation of the central Eastern Desert, Egypt: major subdivisions and depositional setting. American Association of Petroleum Geologists Bulletin, v. 63, no. 6, p. 975-983. 